\title{
Right Arm
}

National Cancer Institute

\section{Source}

National Cancer Institute. Right Arm. NCI Thesaurus. Code C105636.

The portion of the upper extremity between the shoulder and the wrist and located on the right side of the body. 